\title{
Synovial Chondromatosis of the Elbow
}

\author{
Damjan Dimnjaković, Ivan Bojanić, Alan Mahnik and Tomislav Smoljanović \\ University of Zagreb, School of Medicine, Zagreb University Hospital Center, Department of Orthopaedic Surgery, Zagreb, Croatia
}

\begin{abstract}
A B S T R A C T
Synovial chondromatosis (SC) is a rare, mostly benign proliferation of the synovium of the joint, tendon or bursa which results in the formation of loose bodies. It can appear in one of 33 described localisations, but it is most common in the knee. In our study we gathered a group of 7 patients ( 6 male and 1 female) with SC of the elbow, which underwent arthroscopic surgery of the elbow, performing both removal of the loose bodies and complete synovectomy. Mayo Elbow Performance Score (MEPS) was used to evaluate and compare the patients' condition before the operation and at the final follow-up, 31 months, on average, after the operation (range 18-56 months). All patients had poor MEPS before the operation, with an average of 40.7 (range 15-50 points). At the final follow-up, 6 patients had a good or excellent MEPS, while a poor MEPS was present in a single patient. The average MEPS was 85 (range 45-100 points). The one patient who's MEPS remained poor developed heterotopic ossification in the same elbow shortly after arthroscopic surgery. This patient was reoperated 8 months later using an open technique. No other complications occurred in the rest of the operated patients and no recurrence of SC occurred in any of the operated patients. Our results confirm that arthroscopic removal of loose bodies and complete synovectomy should be the treatment of choice for SC of the elbow.
\end{abstract}

Key words: synovial chondromatosis, elbow, treatment, arthroscopy, heterotopic ossification

\section{Introduction}

Synovial chondromatosis (SC) is a proliferation of the synovium of a joint, tendon or bursa which results in the formation of loose bodies ${ }^{1-3}$. In most cases the proliferation is benign, although there is a possibility of malignant transformation ${ }^{1-3}$. There are 33 localisations of SC described in the literature, the most common being the $\mathrm{knee}^{3}$.

It is very important to be aware that there exist 2 types of SC - primary and secondary ${ }^{1-3}$. In primary SC, ectopic chondral particles are formed de novo i.e. there is no other pathology present in the joint which could trigger synovial proliferation and formation of loose bo$\operatorname{dies}^{1-3}$. Conversely, secondary SC affects the joint once there are already other pathological changes present in the joint ${ }^{3}$. In most cases degenerative changes (i.e. osteoarthritis) are present in the joint and are the most common condition associated with secondary SC, but conditions like osteochondritis dissecans or rheumatoid arthritis can also lead to such alterations in the joint ${ }^{3}$. In these conditions loose bodies in the joint may build up in the synovium and thus stimulate the synovial proliferation $^{3}$.
Although the elbow is rarely affected, it can cause significant difficulties, preventing the person from performing everyday activities concerning the elbow. SC of the elbow was first described by Henderson in $1918^{4}$. Since this time authors have recommended surgical treatment for symptomatic SC, as it may cause disabling mechanical symptoms and pain ${ }^{1-3}$. Previously, although the general trend was to initially perform open surgery, the ever broadening scope of arthroscopically treatable illnesses has grown to encompass SC as well; therefore the trend is to treat the SC of the elbow arthroscopically ${ }^{4-11}$.

The aim of this article is to present our results with a 5-portal-approach arthroscopic surgery of the elbow in the treatment of SC of the elbow with complete synovectomy and removal of loose bodies.

\section{Materials and Methods}

Seven patients, 6 male and 1 female, were treated for $\mathrm{SC}$ of the elbow by the same surgeon (I.B.) at our institution from 2006 to 2010 . The general information about the patients is contained in Table 1 . 
TABLE 1

RESULTS OF TREATMENT IN OUR PATIENTS WITH SYNOVIAL CHONDROMATOSIS OF THE ELBOW EVALUATED BY THE MEPS*

\begin{tabular}{|c|c|c|c|c|c|c|c|}
\hline $\begin{array}{l}\text { Age (years)/ } \\
\text { Sex }\end{array}$ & $\begin{array}{c}\text { Side } \\
(+ \text { if domi- } \\
\text { nant side })\end{array}$ & $\begin{array}{l}\text { Duration of } \\
\text { symptoms be- } \\
\text { fore the opera- } \\
\text { tion (months) }\end{array}$ & $\begin{array}{l}\text { Leading } \\
\text { symptom }\end{array}$ & $\begin{array}{l}\text { Decompression } \\
\text { of the ulnar } \\
\text { nerve was } \\
\text { performed }\end{array}$ & $\begin{array}{l}\text { Follow-up } \\
\text { (months) }\end{array}$ & $\begin{array}{l}\text { Preoperative } \\
\text { MEPS }\end{array}$ & $\begin{array}{l}\text { MEPS at final } \\
\text { follow-up }\end{array}$ \\
\hline $51 / \mathrm{M}$ & $\mathrm{R}(+)$ & 60 & Decreased ROM** & No & 56 & 15 & 75 \\
\hline $56 / \mathrm{M}$ & $\mathrm{R}(+)$ & 18 & Decreased ROM & No & 43 & 40 & 95 \\
\hline $41 / M^{* * *}$ & $\mathrm{R}(+)$ & 12 & Decreased ROM & No & 32 & 50 & 45 \\
\hline $45 / \mathrm{M}$ & $\mathrm{L}(-)$ & 60 & Pain & Yes & 24 & 40 & 100 \\
\hline $32 / \mathrm{M}$ & $\mathrm{R}(+)$ & 36 & Pain & Yes & 23 & 45 & 85 \\
\hline $51 / \mathrm{M}$ & $\mathrm{R}(+)$ & 60 & Decreased ROM & Yes & 21 & 45 & 95 \\
\hline $23 / \mathrm{F}$ & $\mathrm{L}(-)$ & 18 & Pain & No & 18 & 50 & 100 \\
\hline
\end{tabular}

* MEPS - Mayo Elbow Performance Score, ** ROM - range of motion, *** Patient had a postoperative complication-heterotopic ossification, open surgery was performed 8 months after arthroscopy

The symptoms were present for 37.7 months on average (range 12-60 months). All patients suffered from both pain during elbow-loading activities and an inability to perform full extension in the elbow. In addition to these symptoms, 3 patients also complained of paresthesias and hypoesthesias in the ulnar nerve distribution. The preoperative electromyoneurography (EMNG) done in these patients, suggested these symptoms were provoked by the ulnar nerve compression at the elbow. All patients underwent X-ray imaging as well as magnetic resonance imaging (MRI) of the affected elbow, which confirmed the presence of loose bodies and synovial proliferation.

At the time of operation the mean age of the patients was 42.7 years (range $23-51$ years). The surgical treatment used in all patients was arthroscopy of the elbow, using an approach through 5 portals, thus enabling complete synovectomy and removal of the loose bodies.

Elbow arthroscopy was performed in general anaesthesia, using tourniquet control. Patients were placed in the prone position with the arm supported in a holder with the shoulder in $90^{\circ}$ abduction, the elbow in $90^{\circ}$ flexion and the forearm pointed towards the floor. Because topographic landmarks can be difficult to localize after joint distension, the elbow is carefully palpated to identify and demarcate the medial and lateral humeral epicondyles and the tip of the olecranon. These bony landmarks and portal sites are marked on the skin before joint distension, as shown in Figure 1.

In 3 patients who had symptoms of ulnar nerve palsy, we performed in-situ decompression of the ulnar nerve at the elbow, before arthroscopy, but after the demarcation of bony landmarks. A small incision was made at a midpoint between the olecranon and the medial epicondyle. After the superficial dissection, the nerve was identified and exposed. Scissors were used to cut through the arcuate ligament of Osborne (i.e. roof of the cubital tunnel), releasing the aponeurosis even further, following the nerve position between the two heads of flexor carpi ulnaris. The surgeon went through maximum possible elbow range of motion in that moment, checking for possible ulnar nerve subluxation after the decompression. After completing the in-situ decompression of the ulnar nerve, we continued with the planned arthroscopy of the elbow.

In all patients arthroscopy was performed using a 4 $\mathrm{mm}-30^{\circ}$ arthroscope and arthroscopic manual instruments, radiofrequency instruments, as well as power shavers, burrs and an arthroscopic pump for irrigation. We used 5 portals to approach the elbow joint. Joint distention is achieved by placing an 18-gauge spinal needle into the joint through the direct lateral portal (the lateral soft spot bordered by the radial head, lateral epicondyle, and tip of the olecranon) and injecting 15 to $25 \mathrm{~mL}$ of saline solution.

At first the anterior compartment was approached through the proximal anteromedial portal, with the entry achieved using a modification of the Seldinger technique over a guidewire. The proximal anterolateral por-

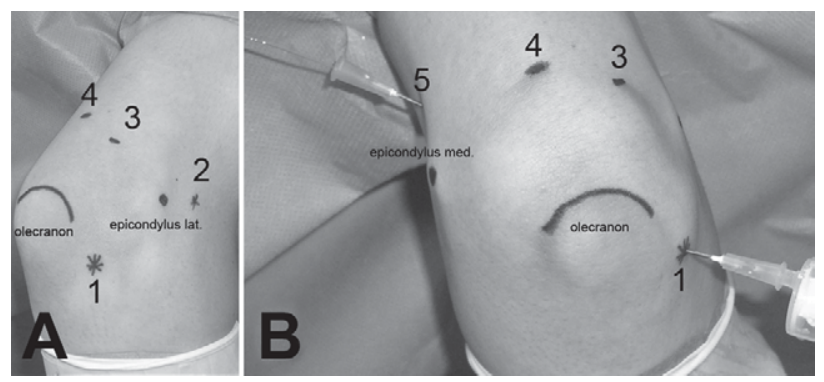

Fig. 1. Preoperative demarcation of bony landmarks and portals (1 - direct lateral portal (»soft spot «), 2-proximal anterolateral portal, 3 - posterolateral portal, 4 - direct posterior portal, 5 proximal anteromedial portal) on the skin before elbow arthroscopy. a) Dorsolateral view - identified surface landmarks include the olecranon and lateral epicondyle. b) Direct dorsal viewidentified surface landmarks include the olecranon and medial epicondyle. An intramuscular syringe is used through the direct lateral portal to fill the joint with saline, the eruption of which from the needle at proximal anteromedial portal indicates that the portal is correctly placed. 


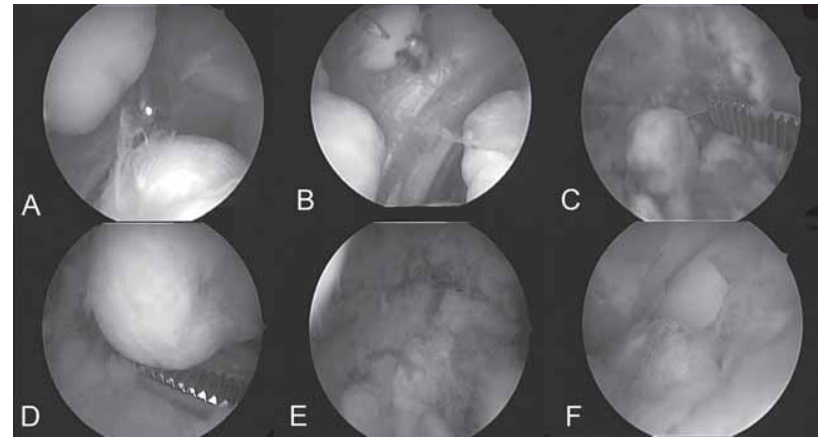

Fig. 2. Sequential arthroscopic views of a patient's elbow undergoing loose body removal and complete synovectomy for synovial chondromatosis. a) Anterior compartment of the elbow, seen through the proximal anteromedial portal, in which loose bodies can be observed. b) Extraction of a loose body from the anterior compartment. c) Loose body extraction from the posterior compartment - synovitis visible throughout. d) Loose body extraction from the posterior compartment. e) Pronounced synovitis visible upon removal of all loose bodies from the posterior compartment. f) Synovitis around the radial head, as seen through the "soft spot «.

tal was established under direct visualisation, with the aid of the spinal needle. These portals were interchangeably used to evaluate the anterior compartment, followed by the removal of the loose bodies as well as performing a complete synovectomy of the compartment (Figure 2). The olecranon fossa was reached through the posterolateral and the direct posterior portal. Both portals were interchangeably used to evaluate the olecranon fossa, remove loose bodies and perform the synovectomy. Although the direct lateral portal is used at the very end of the operation, it is an essential component of elbow arthroscopy, because it enables visualization of the posterolateral recess, thus making it possible to completely visualize the posterior compartment of the elbow. The direct lateral portal is also used interchangeably with the posterolateral portal to facilitate arthroscopic synovectomy and removal of loose bodies from the posterior compartment. During the operation, biopsy samples of the proliferative synovium were taken from both anterior and posterior compartments and analyzed by a senior pathologist, who confirmed SC in all cases.

At the end of the operation 2 drains were placed, one in the anterior and the other in the posterior compartment. The drains were removed 48 hours after the operation and the patients underwent gradually intensifying physical therapy to gain full range of motion of their shoulder, elbow and wrist. It is very important to start with the exercises as soon as possible to avoid range of motion deficit which is later much more difficult to regain. Continuous passive motion machines (CPM) were used for the first 3 weeks to gain full range of motion of the elbow, whereas the patients who didn't manage to gain normal extension after 2 to 3 weeks used the static extension splint. After the initial gain in elbow motion patients were advised to continue physical therapy, which in the second phase also included a strengthening pro- gram, along with the continued passive and active motion exercises.

An independent examiner, who was not involved in their initial care, reviewed the patients' records retrospectively, researching the date of the operation, their preoperative clinical condition and radiographic images. At final follow-up patients were examined and questioned about the function of their operated elbow and whether there were any complications. Patients were asked to complete a Mayo Elbow Performance Score (MEPS), which was then compared to the preoperative MEPS $^{12}$. The total score, with a maximum of 100 points was assessed by evaluating 4 specific parameters: pain (maximum 45 points), range of motion (maximum 20 points), stability (maximum 10 points) and function (maximum 25 points) ${ }^{12}$. The patients' condition was then assessed as either excellent, if scoring 90-100 points, good, if scoring 75-89 points, fair, if scoring 60-74 points and poor if scoring less than 60 points $^{12}$.

\section{Results}

All 7 patients were available at the latest follow-up (Table 1). Mean follow-up was 31 months (range 18-56). Mean preoperative evaluation score was 40.7 (range 1550 ), which was rated as poor. In all patients arthroscopic removal of loose bodies and complete synovectomy of the elbow were performed. The mean postoperative score at final follow-up improved to 85 (range 45-100), which was rated as good. Excluding the single patient who developed heterotopic ossification (HO), the results were excellent in 4 patients and good in two, according to the MEPS.

There was a complication in a 41-year-old patient who had a significant local haematoma of the upper and lower arm, which appeared immediately after the operation. The surgical technique was the same as in all other patients and there were no intraoperative complications. The haematoma was present during the next 2 weeks after the operation and despite intensive physical therapy, range of motion of the elbow decreased, accompanied by local swelling, locking, and pain. X-ray images of the elbow taken 5 weeks after the operation, showed ectopic ossifications in development, with a lucent zone between cortex and centre of ossification (»string sign «), with peripheral density of calcification (Figure 3). Fourteen weeks after the operation the ossifications progressed, growing even larger and being more clearly visible on $\mathrm{X}$-ray. The diagnosis of HO was confirmed. We waited for the ectopic bone to become mature, performing X-ray controls, until delineation of trabeculation was noticed in the $\mathrm{HO}$, suggesting bone maturity and at that moment the operation was scheduled. It was performed 8 months after the arthroscopy. An open procedure using an extended Kocher incision was necessary to excise the $\mathrm{HO}$ from the anterior aspect of the elbow, as shown in Figure 3 . The follow-up period for this patient was 32 months. During this period no recurrence of HO was noted, but the patient had a contracture of the elbow, with motion 


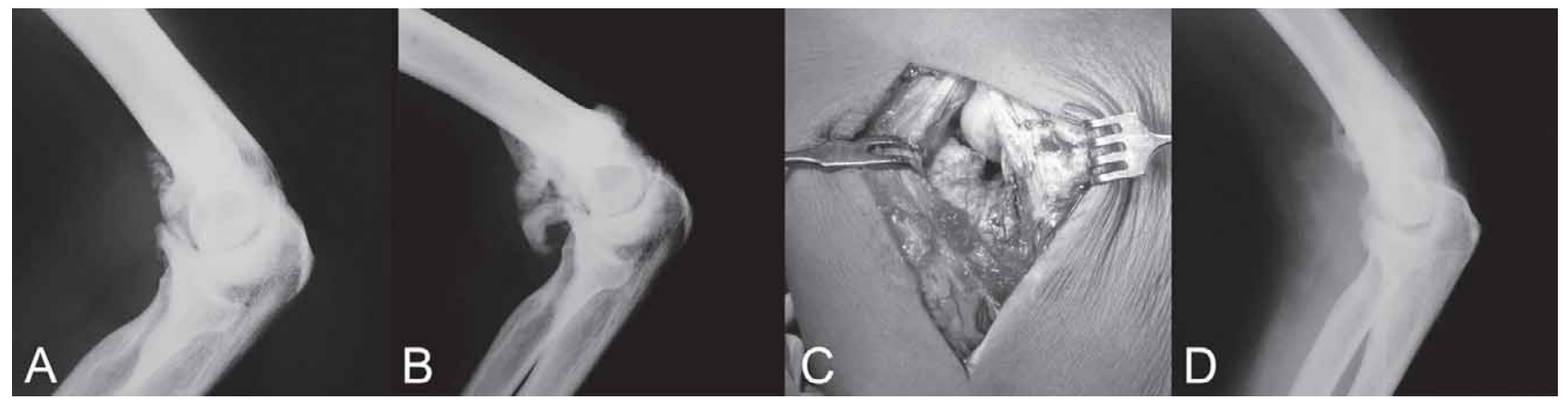

Fig. 3. Follow-up of one patient who developed postoperative heterotopic ossification (HO). a) Standard lateral plain film radiograph of the patient's elbow at 5 weeks after arthroscopic surgery with visible early HO. b) Plain film radiograph at 14 weeks after arthroscopic surgery with visible larger HO. c) Photograph taken during open procedure using an extended Kocher incision, the HO can be seen (procedure performed 8 months after initial arthroscopic surgery). d) Plain film radiograph taken 18 weeks after surgery with no visible recurrence of $\mathrm{HO}$.

ranging from $15^{\circ}-110^{\circ}$, a problem which remained unchanged during the follow-up period.

No recurrence of SC occurred in any of the operated patients. All 3 patients who had ulnar nerve decompression recovered well and were relieved of their neurological symptoms after the surgery. No other complications occurred in the rest of the operated patients.

\section{Discussion and Conclusion}

$\mathrm{SC}$ is a rare condition characterized by the synovial proliferation inside or, rarely, outside the joint ${ }^{1-3}$. In most of our cases classical symptoms are present, including pain, swelling, locking and limited extension of the elbow, which is usually the first, but also sometimes a neglected symptom ${ }^{3,4}$. During a longer period, synovial proliferation may extend beyond the elbow joint, causing the extraarticular pain or discomfort. Additionally, Fahmy et al. ${ }^{13}$ and Ruth et al. ${ }^{14}$ each described a case with a patient presenting with neurological symptoms as a result of the ulnar nerve compression. There are also cases in which patients presented with leading symptoms other than pain or decreased range of motion as their primary difficulty, such as a palpable mass in the anterior part of the elbow, as described in two separate studies ${ }^{7,15}$. Regardless of the leading symptoms, once diagnosed, SC must be treated surgically.

The goals of surgical treatment of SC are the prevention of disease recurrence and delay of secondary osteoarthritis ${ }^{1-11}$. These goals are generally accomplished by removal of loose bodies and synovectomy. There have been some controversies surrounding the operative treatment of SC in the past, mainly whether or not synovectomy should be performed ${ }^{16}$. Some authors suggested only removal of the loose bodies, claiming there was no difference in results and recurrence rate ${ }^{17}$. For articular $\mathrm{SC}$, the recurrence rate has been estimated to be from 11.5 to $37.5 \%$ after operative treatment, with most recurrences occurring more than 5 years after the surge$\mathrm{ry}^{18,19}$. The main cause of recurrences is assumed to be an insufficient removal of the pathological tissue, i.e. partial synovectomy ${ }^{18,19}$. Today there are researches which embrace the standpoint that complete synovectomy should be performed to minimize the risk of recurrence ${ }^{18,19}$. Although we do not have more than 5-years follow-up in our patients to confirm a lack of recurrence, we still believe our extensive synovectomy will lead to a lower recurrence rate. In addition to this, Ogilvie-Harris and Saleh ${ }^{18}$ suggested that complete synovectomy should be performed for two reasons. Firstly, there is less chance of local recurrence of SC, and secondly, minimization of the risk of malignant transformation, which can occur more than five years after the initial surgical treatment. The malignant transformation is a rare condition which can lead to development of synovial chondrosarcoma and while it is typically followed by long lasting symptoms, it is also in close relation to the rate of local recurrence ${ }^{3}$.

In the last 15 years there have been some articles in which authors suggested elbow arthroscopy for the surgical treatment of $\mathrm{SC}^{3,5,8,10}$. Elbow arthroscopy is a technically demanding procedure with a steep learning curve, but during the last decade, arthroscopy has been used with increasing frequency to diagnose and treat more and more types of elbow pathologies ${ }^{20-22}$. Although elbow arthroscopy is a relatively safe procedure, the reported complication rate (10\%) is higher than that seen with knee and shoulder arthroscopy ( $1 \%$ to $2 \%)^{21,22}$. The reported complications for elbow arthroscopy included compartment syndrome, septic arthritis, superficial infection, persistent drainage from portal sites, and, most frequently, nerve injuries (transient or permanent) ${ }^{21,22}$. Arthroscopic findings during elbow surgery in patients with SC typically include a hypertrophic synovium and multiple loose bodies, often described as "snowstorm $\aleph^{23}$. Some of the many advantages over open-surgery are shorter postoperative rehabilitation $(2.4$ months after arthroscopy in contrast to 4.6 months after open-surgery) and the shorter hospital stay ${ }^{20,21}$. Also worth mentioning is the better joint visualization during arthroscopic operations as well as fewer traumas to the joint ${ }^{20,21}$.

Heterotopic ossification following arthroscopy is uncommon in any joint ${ }^{24-26}$. For elbow arthroscopy, few 
cases have been reported previously ${ }^{24-26}$. Although the main cause of the HO remains unclear, researches have implicated that genetic predisposition, local tissue trauma (whether caused by injury or surgery), mechanical factors, neural abnormalities (brain or spinal cord injury), thermal injury, and systemic factors play a role in both the initiation and aggravation of $\mathrm{HO}^{24-28}$. Various aspects of surgical procedures have also been implicated and include the operative time, local soft tissue trauma, haematoma formation, and disseminated bone dust ${ }^{27,28}$. Treating HO also involves patient education and patience. It is important to wait for the HO to fully mature before attempting to excise it from the elbow ${ }^{27,28}$. The maturation of the ectopic bone is important because at that time, the bony fragment has a pseudocapsule and is less biologically active, thus reducing the risk of postoperative recurrence or secondary contractures ${ }^{27,28}$. Among the risk factors generally known for development of $\mathrm{HO}$, besides the local haematoma in the early postoperative stage, our patient also had a brain injury, which happened more than 10 years before the first elbow operation. To reduce the risk of $\mathrm{HO}$ and its functional consequences after elbow arthroscopy, we, as well as Gofton and $\mathrm{King}^{24}$, suggest HO prophylaxis using a 2-week course of Indometacin (75 mg daily in divided doses) in the patients following extensive arthroscopic surgery of the elbow, particularly after release of elbow contractures, synovectomy, radial head excisions, and fracture treatment, i.e. in which there is increasing local soft tissue trauma and bone debris generated. We also suggest this kind of prophylaxis after the elbow arthroscopy in all patients who have specific risk factor for development of $\mathrm{HO}$, such as, diffuse idiopathic skeletal hyperostosis (DISH), ankylosing spondylitis, hypertrophic osteoarthritis or previous $\mathrm{HO}$.

In patients with ulnar nerve palsy we first performed in-situ decompression of the ulnar nerve in the same act as the arthroscopy. We decided to treat the patient with this procedure because it is a simple technique with a low risk of local tissue trauma when compared with some other surgical treatment methods in patients with ulnar nerve entrapment at the elbow ${ }^{29-31}$. The main goals were to release the compression sites, preserve vascularity of the ulnar nerve and to allow early mobilization of the elbow $^{29-31}$. It is a widely accepted opinion that immobilization after the in-situ decompression is unnecessary; the main idea being to allow patients to perform active motion of the elbow as much as they can and to make sure the rehabilitation protocol is not disturbed ${ }^{29-31}$. Some authors warn about the possible risk of nerve subluxation and new compression of the ulnar nerve after this operation ${ }^{29-31}$. Even though there are different opinions as to whether or not the ulnar nerve subluxation leads to friction neuritis, the subluxation should be avoided by limiting the decompression proximally to a line between the medial epicondyle and the tip of olecranon ${ }^{29-31}$.

After a mid-term follow-up (average 31 months; range 18-55) all but one patient, who developed HO, had improved symptoms regarding their elbow, scoring a higher MEPS compared to their preoperative condition. Our follow-up was shorter compared to two other major studies regarding arthroscopy in patients with $\mathrm{SC}$ and this is the main limitation of our study ${ }^{5,8}$. It is important for future studies to have larger group of patients which should be followed-up on a longer term. Recurrence rate and malignant transformation should also be compared between patients who underwent removal of loose bodies with patients who underwent both removal of loose bodies and complete synovectomy. To our knowledge there are no other studies with as many patients in such a short time period. This is definitely an advantage of this study, as well as the fact that all of our patients were operated on by the same surgeon using the same technique, i.e. arthroscopic removal of loose bodies and complete synovectomy. In contrast, in the study of Flury et al. ${ }^{8} 19$ of 24 (79\%) patients were operated arthroscopically and complete synovectomy was performed only in some patients, while in a study by Mueller et al. ${ }^{5}$ only 4 of $12(33 \%)$ patients were operated arthroscopically.

Regarding the mentioned facts, it is our opinion that a complete synovectomy should be performed in all patients with SC. Our results confirm that arthroscopic removal of loose bodies and complete synovectomy should be the treatment of choice for SC of the elbow.

\section{R E F E R E N C E S}

1. MURPHEY MD, VIDAL JA, FANBURG-SMITH JC, GAJEWSKI DA, Radiographics, 27 (2007) 1465. DOI: 10.1148/rg.275075116. - 2 . MCKENZIE G, RABY N, RITCHIE D, Eur Radiol, 18 (2008) 2662. DOI: 10.1007/s00330-008-1024-8. - 3. BOJANIĆ I, BATELJA VULETIĆ L, TROHA I, SMOLJANOVIĆ T, BORIĆ I, SEIWERTH S, Liječ Vjesn, 132 (2010) 102. - 4. KAMINENI S, O'DRISCOLL SW, MORREY BF, J Bone Joint Surg Br, 84 (2002) 96110.1302/0301-620X.84B7.12766. DOI: 10 1302/0301-620X.84B7.12766 - 5. MUELLER T, BARTHEL T, CRAMER A, WERNER A, GOHLKE F, J Shoulder Elbow Surg, 9 (2000) 319. DOI: 10.1067/mse.2000.106744. - 6. JAZRAWI LM, ONG B, JAZRAWI AJ, ROSE D, Am J Orthop, 30 (2001) 223. - 7. DE SMET L, Clin Rheumatol, 21 (2002) 403. DOI: 10.1007/s100670200107. — 8. FLURY MP, GOLDHAHN J, DRERUP S, SIMMEN BR, Arthroscopy, 24 (2008) 520e1. DOI: 10.1016/j.arthro.2007.12.002. - 9. KIM CH, KIM SH, KIM MS, SHANG CH, J Korean Neurosurg Soc, 43 (2008) 109. DOI: 10.3340/jkns.2008.43. 2.109. - 10. PLOMINSKI J, KWIATKOWSKI K, PAWLIK J, KOKTYSZ
R, Artroskopia i Chirurgia Stawow, 4 (2008) 27. - 11. GRIESSER MJ, HARRIS JD, LIKES RL, JONES GL, Am J Orthop, 40 (2011) 253. — 12. MORREY BF,AN KN, CHAO EYS, Functional evaluation of the elbow. In: MORREY BF (Ed) The elbow and its disorders (WB Saunders, Philadelphia,1993). - 13. FAHMY NR, NOBLE J, Hand, 13 (1981) 308. - 14. RUTH RM, GROVES RJ, Am J Orthop, 25 (1996) 843. — 15. MATSUMOTO K, HUKUDA S, FUJITA M, KAKIMOTO A, TACHIBANA S, J Bone Joint Surg Am, 78 (1996) 275. - 16. DORFMANN H, DE BIE B, BONVARLET JP, BOYER T, Arthroscopy, 5 (1989) 48. - 17. SHPITZER T, GANEL A, ENGELBERG S, Acta Orthop Scand, 61 (1990) 567. - 18. OGILVIE-HARRIS DJ, SALEH K, Arthroscopy, 10 (1994) 166. — 19. BOJANIĆ I, BERGOVEC M, SMOLJANOVIĆ T, Foot Ankle Int, 30 (2009) 1120. DOI: 10.3113/FAI.2009.1120. - 20. DODSON CC, NHO SJ, WILLIAMS RJ, ALTCHEK DW, J Am Acad Orthop Surg, 16 (2008) 574. — 21. BOJANIĆ I, SMOLJANOVIĆ T, MAHNIK A, Liječ Vjesn, 132 (2010) 238. - 22. KELLY EW, MORREY BF, O'DRISCOLL SW, J Bone Joint Surg 
Am, 83 (2001) 25. - 23. YORGANCIGIL H, KARAHAN N, BAYDAR ML, Arthroscopy, 20 (2004) e113. DOI: 10.1016/j.arthro.2004.07.014. - 24 . GOFTON WT, KING GJ, Arthroscopy, 17 (2001) E2. DOI: 10.1053/jars. 2001.16283. - 25. SODHA S, NAGDA SH, SENNETT BJ, Arthroscopy, 22 (2006) 802.e1. - 26. HUGHES SC, HILDEBRAND KA, J Shoulder Elbow Surg, 19 (2010) e1. DOI: 10.1016/j.jse.2009.04.015 — 27. SUMMERFIELD SL, DIGIOVANNI C, WEISS AP, J Shoulder Elbow Surg, 6 (1997)

\section{Bojanić}

University of Zagreb, School of Medicine, Zagreb University Hospital Center, Department of Orthopaedic Surgery, Šalata 6, 10000 Zagreb, Croatia

e-mail:artroboj@yahoo.com
321 - 28. HSU JE, KEENAN MA, UPOJ, 20 (2010) 126. - 29. ELHAS SAN B, STEINMANN SP, J Am Acad Orthop Surg, 15 (2007) 672. — 30 MANDELLI C, BAIGUINI M, Neurocirugía, 20 (2009) 31. - 31. MITSIONIS GI, MANDOUDIS GN, PASCHOS NK, KOROMPILIAS AV, BE RIS AE, J Shoulder Elbow Surg, 19 (2010) 513. DOI: 10.1016/j.jse.2009. 10.014 .

\section{SINOVIJALNA HONDROMATOZA LAKTA}

\section{S A Ž E T A K}

Sinovijalna hondromatoza (SC) jest rijetka, benigna proliferativna bolest sinovijalne ovojnice zgloba, tetive ili burze koja u konačnici rezultira novostvorenim slobodnim tijelima. Za nju je tipično da zahvaća samo jednu lokalizaciju kod pojedinog bolesnika i to najčešće koljeno, a do danas su opisane 33 različite lokalizacije SC-a. Ovo je istraživanje provedeno na skupini od 7 bolesnika ( 6 muškaraca i 1 žena) kod kojih je poradi SC lakta učinjen artroskopski zahvat tijekom kojeg su izvađena slobodna zglobna tijela i učinjena potpuna sinoviektomija. Autor koji osobno nije bio involviran u liječenje bolesnika na završnom je kontrolnom pregledu (prosječno poslijeoperacijsko praćenje iznosilo je 31 mjesec) evaluirao bolesnike koristeći se standardiziranim upitnikom (Mayo Elbow Performance Score - MEPS). Svi su bolesnici imali nizak MEPS prije zahvata (između 15 i 50 bodova), s prosjekom od 40,7. Na završnom kontrolnom pregledu 6 je bolesnika imalo dobar ili odličan rezultat, dok je u jednog bolesnika rezultat bio loš. MEPS se na završnom kontrolnom pregledu kretao između 45 i 100 bodova, s prosjekom od 85. U bolesnika s lošim rezultatom došlo je do pojave heterotopične osifikacije u području lakta nakon artroskopskog zahvata, zbog čega je bolesnik ponovno operiran 8 mjeseci nakon prvog zahvata i to otvorenim načinom. U praćenoj skupini bolesnika nisu se pojavile nikakve druge komplikacije za vrijeme ili nakon artroskopskog zahvata, a valja istaknuti da se tijekom praćenja bolesnika nisu niti uočili znaci eventualne ponovne pojave SC-a. Rezultati ovog istraživanja upućuju da je artroskopija lakta tijekom koje valja izvaditi sva slobodna zglobna tijela i učiniti potpunu sinoviektomiju metoda izbora za liječenje SC-a lakta. 